E. Stepovaja ${ }^{1}$, Cand. Sc. (Tech.), Assoc. Prof., orcid.org/0000-0002-6346-5484, Yu. Holik ${ }^{1}$, Cand. Sc. (Tech.), Prof., orcid.org/0000-0002-5429-6746, K. Fran̆a ${ }^{2}$, PhD (Ing.), Prof., orcid.org/0000-0002-2319-7833

\title{
METHODS FOR PRECAUTIONARY MANAGEMENT FOR ENVIRONMENTAL SAFETY AT ENERGY FACILITIES
}

Purpose. The purpose of this work is to find out the methods of preventive management for forecasting environmental safety at the enterprises of the energy industry and the example of the main oil pipeline, taking into account the factors that characterize the processes of electrochemical corrosion.

Methodology. Studies have shown that the main role in the corrosion process on the damaged section of the pipeline in contact plays an aggressive solutions work makrohalvanichnyh couples. The problem of modeling electrochemical corrosion steel pipe surface. On the basis of the model proposed by galvanic corrosion method of calculating the residual life of the safe operation of the main pipeline.

Findings. Based on analysis and case studies, based on mathematical models of corrosion of the surface areas of oil dependence obtained to determine the reduction of the wall thickness of the pipeline and forecasting resource environmentally safe operation of pipelines, which are subject to falling electrolytic environments on the affected area of the pipeline through controls to some electrochemical parameters. The method of forecasting is focused on getting a non-destructive way to output data on real structures in operation and to reliably assess the safe operation of the pipeline sections.

Originality. Scientific novelty of the research is as follows: the technique of estimation of residual life plot oil based corrosion processes on the surface of the pipeline when working macro galvanic elements; developed and researched mathematical model of macro galvanic couple at local corrosion on steel pipe surface areas for which settlement is to predict corrosion loss on damaged sections of the pipeline when hit them aggressive electrolytic solutions regardless of their chemical composition.

Practical value. The method of calculation of the residual resource of safe operation of the main section of the pipeline makes it possible to rationally plan the repair work, to predict a realistic timetable construction work, review the operation mode. The proposed method is aimed at obtaining the initial data nondestructive method on real structures in the conditions of their operation. rosion

Keywords: preventive management, environmental safety, energy sector enterprises, residual life, main oil pipeline, cor-

Introduction. The precautionary approaches and precautionary management generally defines actions on issues considered to be uncertain regarding possible future hazards. And today, science offers a number of useful ideas and concrete precautionary methods to justify discretionary decisions to reducing the risk of environmental contamination. Regarding the Highly Polluted Areas, among which is Ukraine, the most internationally established methods have become, in particular, Standards and Thresholds, Environmental Impact Assessment (EIA) process and strategic environmental assessment (SEA) [1, 2]. In such matters, a great deal of consideration is given to account for safety issues and the potential environmental risks of energy facilities, which are characterized as projects that may have a large-scale negative environmental, including health, effects. The most important such facilities involve oil pipelines that are those designed to carry oil from areas of extraction to refineries, storage facilities, rail, river and seaport loading facilities, or to spur pipelines for delivering oil to specific organizations.

(C) Stepovaja E., Holik Yu., Fraňa K., 2018
Ukraine's oil pipeline system is operated for 20-42 years on average, depending on the commissioning period of its components. During the period of operation, a considerable part of main oil pipelines and processing equipment has got its service life expired, has been repeatedly subject to repairs and overhauls and has become morally obsolete. Having been designed and manufactured in accordance with the requirements of normative documents, the pipelines must be resistant to environmental stress. But manufacturing defects and damages promote beginning and development of corrosion processes on a pipeline.

One of the serious problems of operation of main oil pipelines is their proneness to accident - an unforeseen failure of a linear portion of a pipeline, which is followed by a catastrophic environmental impact.

Improvement of the reliability of operation and maintenance of oil pipeline objects for ensuring of technogenic safety and, therefore, ecologically safe functioning of a pipeline system, is achieved by means of constant performance of a range of works, which include determination of remaining service life of objects of main oil pipelines and prediction of technogenic risk, 
which is possible in case of accidents on oil pipeline sections. Such structures require special attention, periodic monitoring of their capability for work.

Therefore, prediction and evaluation of safe operation of main oil pipelines is a pressing issue, given that the number of such structures grows every year.

Analysis of the recent research. Analysis of the literature [3] showed that predicting the residual life of pipelines is a multifactorial problem of determining the maximum allowable state of their disability. There are no criteria specified maximum allowable state of elements of pipelines that have been in operation more than 200 thousand hours, and methods of forecasting residual resource with the necessary certainty [4].

Existing normative provision of safe operation of pipelines does not fully regulate carrying-out of integral analysis of pipelines state in order to determine their remaining life and predict safe operation because it disregards technical characteristics and parameters which have changed during operation under the influence of external factors, such as corrosive wear [5].

Ensuring environmentally safe operation of the pipelines is largely a problem of increasing their reliability and durability and are difficult complex task that involves finding out technical, technological, economic and organizational aspects. Despite the fact that this problem is the subject of numerous studies of domestic and foreign authors, this time it is still not fully resolved many issues remain open $[6,7]$.

There are proposals on the residual life evaluation in terms of probability of failure on designs. But the methods reflect the general approaches to determining the residual life or require significant experimental studies to obtain statistical characteristics degradation processes on the surface of the pipeline.

Unsolved aspects of the problem. It remains unsolved problem of evaluating the residual life of steel safe operation of the pipeline on the basis of laws of the kinetics of electrochemical corrosion of the pipeline. In this situation, determine the depth of the pipelines, and therefore the residual life using electrochemical laws are specific approach that will characterize this process.

Objectives of the article. The purpose of this work is to addictions to calculate the residual resource of safe operation of pipelines from electrochemical measurements of characteristics pipeline hit in the electrolytic solution in areas where the broken pipe insulation.

Methods. Studies have shown that the main role in the corrosion process on the damaged section of the pipeline in contact plays an aggressive solutions work makrohalvanichnyh couples. The problem of modeling electrochemical corrosion steel pipe surface. On the basis of the model proposed by galvanic corrosion method of calculating the residual life of the safe operation of the main pipeline.

Presentation of the main research. Various studies of steel pipe showed that the environmentally safe use of the term essentially depends on the corrosion resistance of the metal. A considerable part of accidents is caused by corrosion processes. A way to ensure accident-free functioning of underground pipelines is to protect them from in-ground corrosion. For this purpose, the pipelines surface is protected with suitable coatings. During operation, protective coating is destroyed under the influence of external negative factors. As a result, electrochemical contact is established on pipeline sections with defective coating and on sections, where coating is not broken-down.

An underground pipeline is a typical many-electron corrosion system in the form of micro- and macro-galvanic couples placed on its surface. Their operational efficiency is determined by the value of electric potential of individual sections of the pipeline. Generation of corrosion current between anode and cathode sections is due to the influence of a broad range of factors. In practice, conditions for corrosion of pipeline surface always exist. High aggressiveness of soil and presence of defects in insulation coating can significantly intensify the corrosion processes on the outer surface of a pipe.

As soon as the fact of coating failure has been found, the question arises concerning prediction of technogenic risk of oil spill in connection with corrosion of the pipeline.

Solution to questions of timely detection of pipeline corrosion, determination of its depth and area of distribution is connected with a number of difficulties. Pipe wall thickness depends on operating pressure, structural characteristics and strength margin, which includes tolerance on uniform corrosion loss. Strength margin is set as a whole, judging from the available experience, though an accurate prediction of process of pipeline corrosion after earth backing is necessary.

On the oil pipeline sections, where insulation is broken, the conditions are formed for the emergence of macrogalvanic couples, the strength of current of which can be used as a generalized characteristic in determination of losses on pipeline metal.

Electric field near the heterogeneous electrode is considered, the model of which consists of 2 sections of arbitrary width, which differ in steady potentials.

Local corrosion cell is represented by the pipeline section under the insulation coating (cathode) and the pipeline section, where there is no insulation coating (anode) (Figure).

Determination of electric field potential distribution in this case is reduced to solution of two-dimensional Laplace equation

$$
\frac{\partial^{2} \varphi}{\partial \tilde{o}^{2}}+\frac{\partial^{2} \varphi}{\partial \dot{o}^{2}}=0,
$$

where $\varphi$ is potential; $x, y$ are current coordinates.

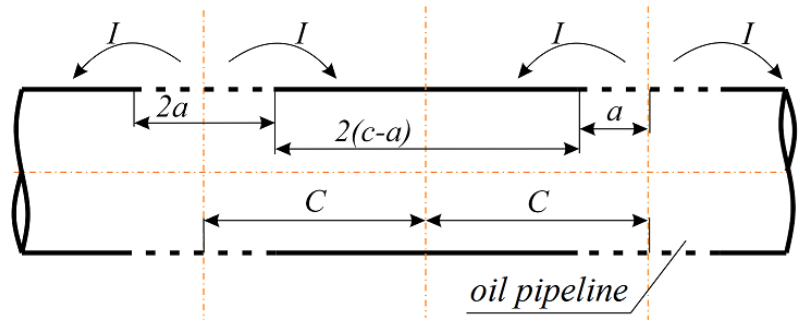

Fig. Local corrosion cell in the pipeline under the earth blanket 
The boundary conditions are defined as follows:

1) at an infinite distance from the surface of the electrode (oil pipeline) no exciters are introduced into the electric field: $\varphi(y \rightarrow \infty, x)=$ const;

2 ) the second one is a consequence of symmetry of the model under consideration $\left.\frac{\partial \varphi}{\partial x}\right|_{x=0}=\left.\frac{\partial \varphi}{\partial x}\right|_{x=c}=0$;

3) conditions on heterogeneous sections are represented as

$$
\begin{aligned}
& \varphi=E_{a}+L d \varphi / d y \quad \text { with } \quad y=0, \quad 0 \leq x<a \\
& \varphi=E k+L d \varphi / d y \quad \text { with } \quad y=0, \quad a \leq x<c,
\end{aligned}
$$

where $L=\gamma \cdot b$; $\gamma$ is electrolytic conductivity; $b$ is coefficient of polarization; $E a$ and $E k$ - without exact potentials of anode and cathode, $\mathrm{mV}$.

Solution of (1) under such boundary conditions is obtained by Euler-Fourier method.

$$
\begin{gathered}
\varphi(x, y)=\frac{a\left(E_{a}-E_{K}\right)+C E_{K}}{c}+ \\
+\frac{2\left(E_{a}-E_{K}\right)}{\pi} \sum_{K=1}^{\infty} \frac{\sin \frac{\pi k}{c} a}{\left(1+\frac{\pi k}{c} L\right) k} \cos \frac{\pi k}{c} x e^{-\frac{\pi k}{c} y} .
\end{gathered}
$$

Given that $i=-\gamma\left(\frac{d \varphi}{d y}\right)_{y=0}$ from (2) we obtain an expression for determination of current density distribution on the surface of one local cell.

$$
i(x)=\frac{2\left(E_{a}-E_{k}\right) \gamma}{\tilde{n}} \sum_{k=1}^{\infty} \frac{\sin \frac{\pi k a}{c} \cos \frac{\pi k x}{c}}{k\left(1+\frac{\pi k L}{c}\right)} .
$$

In accordance with Faraday's law, corrosion loss of metal is calculated by the formula

$$
M=K I t,
$$

where $M$ is metal mass; $I$ is current strength; $t$ is time; $K$ is electrochemical coefficient of metal.

Let us assume that the corrosion damage is of circular shape. Let us consider the corrosive damage on a pipe in the form of an evenly expanding equilateral cone. Suppose that in the last phase the outer diameter of the corrosion damage is equal to the pipe wall thickness $h$. Then

$$
H_{p}=\frac{K i t}{0.167 D}
$$

where $D$ is relative weight of metal; $i$ is density of current flowing through the area of cross section of the damage surface; $i=\frac{I}{a} ; a$ is area of cross section of the damage surface, $a=\pi h^{2} / 2$.

To obtain equation (4), $\quad M=\frac{\pi D h^{3}}{12}$ and $K I t=$ $=\frac{\pi K h^{2} i t}{2}$ were inserted into the left and right side of equation (3), where $h$ is depth (diameter) of corrosion damage; $V$ is volume of corrosion damage, $V=\pi h^{3} / 12$.

Equation (2) shows that $H_{p}$ does not depend on the length or diameter pipes, that this feature is only time and current density. For further analysis we assume that both ends grounded pipes and pipe corrosion has one ulcer in the middle. Then for the case where the electric potentials of the left and right sides of the circuit level electrical current through a defect in the pipe according to Kirchhoff's law can be expressed as

$$
I=I_{1}+I_{p}=\frac{2\left(U_{n}-U_{p}\right)}{R_{g}+R_{p}+R_{n}}=\frac{2 \Delta U}{R_{g}+R_{p}+R_{n}},
$$

where $\Delta U-$ the potential difference in an open element between a grounded point defect in the pipe and tube is $U_{n}-U_{p} ; R_{p}-$ the electrical resistance of the pipe, even $R_{p 1}=R_{p 2} ; R_{g}-$ contact resistance 'ground - ground' on both ends of the pipe, equal $R_{g 1}=R_{g 2}$.

Laboratory through proven that the electrical resistance defect size limit over $10^{3} \mathrm{Om}$. Why such resistance defect will be much greater than the resistance tubes and contact systems 'pipe - soil' $R_{n}>R_{g}>R_{p}$.

Contact resistance of the system 'pipe - soil' in place of the defect is calculated as

$$
R_{n}=\frac{\rho}{2 \pi H}
$$

where $\rho$ - Soil resistivity; $H$ - diameter ulcer.

Lowering $R_{g}$ and $R_{p}$ in equation (4) as extremely small value compared to the value of $R_{\mathrm{n}}$ and expressing $I$ as $\pi i H^{2} / 2$, we get

$$
i=\frac{8 \Delta U}{\rho H} .
$$

For the case of several rising defects along the tubes equation (5) will look like

$$
i=\frac{8 \Delta U}{\rho H n},
$$

where $n$-defects in the tube.

Equation (6) shows that the resistivity of the soil and the total surface area of the pipe in place covering the defect determining current density. Equation (6) describes increasing number of leaks after suffered the first of them. Since the beginning of its corrosion products form a contact with soil that has low resistance, and corrosion rate increases. On the other hand, increasing the surface area of the intersection of corrosive ulcers slows corrosion. When pitting corrosion penetrates the entire thickness of the wall, it reduces the total area of intersection of the surface affected by the current source. In most cases, the corrosion rate of spread will increase again due to leakage of the product to be pumped.

Combining equations (4) and (6) to the time to the first leak

$$
t=\frac{H^{2} D n \rho}{48 K \Delta U} .
$$

We write the (4) as $H_{p} \cdot 0.167 D=K I t$, from here 


$$
t=\frac{H_{p} 0.167 D}{K i} .
$$

Taking into account that $i=\frac{I}{a}, a=\frac{\pi H^{2}}{2}$, have $i=\frac{I 2}{\pi H^{2}}$.

Substituting values into the (7), we get the equation for calculating corrosion prediction for one ulcer

$$
t=\frac{H_{p} 0.167 D \pi H^{2}}{K I 2}
$$

where $H_{p}$ - deep of corrosive ulcers; $D$ - diameter pipeline; $H$ - diameter ulcer; $K$ - electrochemical metal ratio; $I$ - output current.

In the case of several progressive sample calculation is predicting corrosion

$$
t=\frac{H_{p} 0.167 D \pi H^{2}}{K I 2 n},
$$

where $n$ - number of progressive ulcers.

The current value of galvanopary can be obtained after measuring electrochemical parameters required for the real design of the developed methodology.

The critical time for the first break of the pipeline is given by

$$
T=t-t_{e},
$$

where $t$ - time to first oil spill, year; $t_{e}-$ stay pipeline in these conditions.

Conclusions and recommendations for further research. Methodology is developed for prediction of technogenic risk during operation of the main oil pipelines functioning under the condition of electrolytic media entering to the pipeline damaged sections, by means of controlling certain electrochemical parameters.

\section{References.}

1. Palekhov, D., Schmidt, M. and Pivnyak, G., 2008. Standards and Thresholds for EA in Highly Polluted Areas - The Approach of Ukraine. In: Schmidt, M., Glasson, J., Emmelin, L. and Helbron, H., eds. Standards and Thresholds for Impact Assessment. Environmental Protection in the European Union. Volume 3. Springer, Heidelberg [online], pp. 33-48. Available at: <https://www.springer.com/it/book/9783540311409> [Accessed 3 September 2017].

2. Palekhov, D., 2014. Potential for Strategic Environmental Assessment (SEA) as a Regional Planning Instrument in Ukraine. Umweltrecht in Forschung und Praxis, Band 66. Verlag Dr. Kovač, Hamburg [online]. Available at: <https://www.verlagdrkovac.de/978-3-83007896-8.htm > [Accessed 10 November 2017].

3. Poberezhnyj, L., 2017. Corrosion of long-exploded tubular steels in chloride-type media. Naukovyj Visnuk TNTU, 27(5), pp. 114-118.

4. Zhdek, A. and Hrudz, M., 2012. Determination of residual life long exploited oil, taking into account existing defects and corrosion conditions. Naukovy visnyk Ivano-Phrankivskogo natsiionalnogo universytetu naphty $i$ hazu [pdf], 2(32), pp. 58-66. Available at: < http:// nv.nung.edu.ua/sites/nv.nung.edu.ua/files/journals/ 032/12zaydue.pdf $>$ [Accessed 26 September 2017].

5. Rihan, R.O., 2013. Electrochemical Corrosion Behavior of X52 and X60 Steels in Carbon Dioxide Containing Saltwater Solution. Materials Research, 16(1), pp. 227-236. DOI: 10.1590/S1516-14392012005000170. 6. Poberezhniy, L., Stanetskiy, A. and Rudko, V., 2011. Corrosion monitoring transit line. Bulletin TNTU (Mechanics and Materials) [pdf], 16(3), pp. 20-26. Available at: <http://elartu.tntu.edu.ua/bitstream/123456789/ 1957/2/TNTUB2011_v16_No3-Poberezhny L_Stanetsky_A_Rudko_V-Corrosion_monitoring_of_ 20.pdf > [Accessed 15 October 2017].

7. Stepova, O. and Paraschienko, I., 2017. Modeling of the corrosion process in steel oil pipelines in order to improve environmental safety Eastern-European journal of enterprise technologies, industrial and technology systems, 2(1(86)), pp. 15-20. DOI: 10.15587/17294061.2017.96425.

\section{Превентивні методи управління екологічною безпекою на підприємствах енергетичної галузі}

\author{
О. В. Степова ${ }^{1}$, Ю. С. Голік ${ }^{1}$, К. Франа
}

1 - Полтавський національний технічний університет імені Юрія Кондратюка, м. Полтава, Україна, е-таil: golik38@i.ua; alenastepovaja@gmail.com

2 - Технічний університет в Ліберець, м. Ліберець, Чеська Республіка, e-mail: karel.frana@tul.cz

Мета. 3'ясування методів превентивного управління для прогнозування екологічної безпеки на підприємствах енергетичної галузі на прикладі магістрального нафтопроводу з урахуванням факторів, що характеризують процеси електрохімічної корозії.

Методика. Дослідження показали, що головну роль у корозійних процесах на пошкодженій ділянці нафтопроводу при попаданні агресивних розчинів відіграє робота макрогальванічних пар. Розв'язана задача моделювання електрохімічної корозії поверхні стального трубопроводу. На основі розробленої моделі електрохімічної корозії запропонована методика розрахунку залишкового ресурсу екологічно безпечної експлуатації магістрального нафтопроводу.

Результати. На основі аналітичних і практичних досліджень, на базі математичної моделі корозії поверхні ділянки нафтопроводу, отримана залежність для визначення зменшення товщини стінки трубопроводу й прогнозування ресурсу екологічно безпечної експлуатації магістральних нафтопроводів, що працюють за умови потрапляння електролітичних середовищ на вражені ділянки нафтопроводу, шляхом контрою деяких електрохімічних параметрів. Розроблена методика прогнозування орієнтована на отримання вихідних даних неруйнівним способом на реальних конструкціях в умовах експлуатації та дозволяє достовірно оцінити безпечну експлуатацію ділянок нафтопроводу. 
Наукова новизна. Полягає в наступному: розроблена методика оцінки екологічно безпечного ресурсу ділянки нафтопроводу з урахуванням корозійних процесів на поверхні трубопроводу при роботі макрогальванічних елементів; розроблена та досліджена математична модель роботи макрогальванічної пари при локальній корозії на поверхні ділянки стального трубопроводу, розрахунки за якою дозволяють прогнозувати корозійні втрати на пошкоджених ділянках нафтопроводу при попаданні до них агресивних електролітичних розчинів незалежно від їх хімічного складу.

Практична значимість. Розроблена методика розрахунку залишкового ресурсу безпечної експлуатації об'єктів енергетичного сектора, на прикладі нафтопроводу, дає можливість запобігти екологічним наслідкам, прогнозувати, раціонально спланувати ремонтні роботи та переглянути режим їх експлуатації. Запропонована методика орієнтована на отримання вихідних даних неруйнівним методом на реальних конструкціях в умовах їх експлуатації.

Ключові слова: превентивний менеджмент, екологічна безпека, підприємства енергетичного сектоpa, залишковий ресурс, магістральний нафтопровід, корозія

\section{Превентивные методы управления экологической безопасностью на предприятиях энергетического сектора}

\author{
Е. В. Степовая ${ }^{1}$, Ю. С. Голик ${ }^{1}$, К. Франа ${ }^{2}$
}

1 - Полтавский национальный технический университет имени Юрия Кондратюка, г. Полтава, Украина, e-mail: golik38@i.ua; alenastepovaja@gmail.com

2 - Технический университет в Либерец, г. Либерец, Чешская Республика, e-mail: karel.frana@tul.cz

Цель. Установление методов превентивного управления для прогнозирования экологической безопасности на предприятиях энергетической отрасли н примере магистрального нефтепровода с учетом факторов, характеризующих процессы электрохимической коррозии.

Методика. Исследования показали, что главную роль в коррозионных процессах на поврежденном участке нефтепровода при попадании агрессивных растворов играет работа макрогальваничних пар. Решена задача моделирования электрохимической коррозии поверхности стального трубопровода. На основе разработанной модели электрохимической коррозии предложена методика расчета остаточного ресурса безопасной эксплуатации магистрального нефтепровода.

Результаты. На основе аналитических и практических исследований, на базе математической модели коррозии поверхности участка нефтепровода, получена зависимость для определения утоньшения стенки трубопровода и прогнозирования ресурса экологически безопасной эксплуатации магистральных нефтепроводов, работающих при условии попадания электролитических сред на пораженные участки нефтепровода, путем контроля некоторых электрохимических параметров. Разработанная методика прогнозирования ориентирована на получение исходных данных неразрушающим способом на реальных предприятиях энергетического сектора в условиях эксплуатации и позволяет более достоверно оценить экологически безопасную эксплуатацию участков нефтепровода.

Научная новизна. Заключается в следующем: на примере нефтепровода разработана методика превентивной оценки экологически безопасного ресурса с учетом коррозионных процессов на поверхности стального трубопровода при работе макрогальваничних элементов; разработана и исследована математическая модель работы макрогальваничной пары при локальной коррозии на поверхности участка трубопровода, расчеты по которой позволяют прогнозировать коррозионные потери на поврежденных участках нефтепровода при попадании в них агрессивных электролитических растворов независимо от их химического состава.

Практическая значимость. Разработанная методика расчета остаточного ресурса безопасной эксплуатации объектов энергетического сектора, на примере нефтепровода, дает возможность предотвратить экологические последствия, прогнозировать, рационально спланировать ремонтные работы и пересмотреть режим их эксплуатации. Предложенная методика ориентирована на получение исходных данных неразрушающим методом на реальных конструкциях в условиях их эксплуатации.

Ключевые слова: превентивный менеджмент, экологическая безопасность, предприятия энергетического сектора, остаточный ресурс, магистральный нефтепровод, коррозия

Рекомендовано до публікації докт. техн. наук B. О. Бондарем. Дата надходження рукопису 20.12.17. 